\title{
STUDY OF REFRIGERATION SYSTEM IMPACT ON VITAMIN C AND TOTAL POLYPHENOLS CONTENT AND MASS VARIATION OF Fragaria vesca L. FOR INNOVATIVE TECHNOLOGIES DEVELOPMENT
}

Fernanda Raquel Wust Schmitz ${ }^{1}$, Tuany Gabriela Hoffmann ${ }^{2}$, Betina Louise Angioletti ${ }^{2}$, Luana Curbani $^{3}$, Sávio Leandro Bertoli ${ }^{4}$, Lisiane Fernandes de Carvalho ${ }^{5}$ e Carolina Krebs de Souza ${ }^{6}$

${ }^{1}$ Universidade Federal de Santa Catarina, Programa de Pós-Graduação em Engenharia Química, Mestre em Engenharia Química

${ }^{2}$ Universidade Regional de Blumenau, Programa de Pós-Graduação em Engenharia Química, Graduada em Engenharia Química

${ }^{3}$ Universidade Regional de Blumenau, Programa de Pós-Graduação em Engenharia Química, Mestre em Engenharia Química

${ }^{4}$ Universidade Regional de Blumenau, Programa de Pós-Graduação em Engenharia Química, Doutor em Engenharia Mecânica

${ }^{5}$ Universidade Regional de Blumenau, Programa de Pós-Graduação em Engenharia Química, Doutora em Engenharia e Ciência de Alimentos

${ }^{6}$ Universidade Regional de Blumenau, Programa de Pós-Graduação em Engenharia Química, Doutora em Chemistry and Toxicology of Foods

E-mail para contato: wust.fernanda@gmail.com

\begin{abstract}
Strawberry is a non-climacteric pseudofruit that has a short shelf life after harvest. Among the factors responsible for the strawberries quality loss are the high metabolic activity and high susceptibility to microbial attack, mainly by fungi. The objective of this work is to study physicochemical parameters of strawberries (Fragaria vesca L.) submitted to different cooling system conditions. Strawberries were stored at temperatures of $2{ }^{\circ} \mathrm{C}$ and $6{ }^{\circ} \mathrm{C}$ with a range of $\pm 1{ }^{\circ} \mathrm{C}$ and packed in polyethylene terephthalate (PET) trays wrapped by polyvinyl chloride (PVC) film. Samples were evaluated for their physicochemical aspects, such as: mass variation, vitamin $\mathrm{C}$ content and total polyphenols. The assays were done in triplicate. The results show that storage at $6{ }^{\circ} \mathrm{C} \pm 1{ }^{\circ} \mathrm{C}$ is better to maintain the strawberries quality stored during 6 days, because under these conditions a lower mass variation was obtained. These parameters are associated with low moisture loss, which also assists in the preservation of polyphenols. And storage at $2{ }^{\circ} \mathrm{C} \pm 1{ }^{\circ} \mathrm{C}$ favored the maintenance of total polyphenols and Vitamin $\mathrm{C}$. With this information it is possible to optimize technologies for this type of food with focus on reducing the environmental impact and waste of food and drinking water, supporting research developed in multinational refrigeration area.
\end{abstract}

Keywords: Food Preservation. Physicochemical Analysis. Range Temperature. Refrigeration Systems. Strawberry. 
Recebido em:

$25 / 06 / 2018$

Aceito em:

$03 / 10 / 2018$

DOI: $10.5965 / 24473650412018045$

\section{INTRODUCTION}

Due to the appreciation of the original taste and quality of fresh food, minimally processed foods have been gaining market space because of their practicality and convenience, as well as providing less preparation time (MORAES et al., 2008). Minimally processed food can be vegetables that have undergone some treatment like cutting, washing, peeling, maintaining its original state (MORETTI, 2007; SANTOS, 2012)

Strawberry presents high perishability, being stored for a limited time (GARCIA, 2009), between 5 and 7 days, mainly due to the high microbial and respiratory activity (AGUAYO, 2006). Post-harvest fruit degradation is usually delayed by storage at low temperatures, in modified atmosphere or by the use of treatments that reduce the product metabolism (GARCIA, 2009). The storage at low temperatures $\left(4{ }^{\circ} \mathrm{C}\right)$ is used to avoid fruit deterioration during post-harvest storage (MORAES et al., 2008; HERNÁNDEZ-MUÑOZ et al., 2008). It is known that low cooling temperatures $\left(5{ }^{\circ} \mathrm{C}\right.$ and $\left.10{ }^{\circ} \mathrm{C}\right)$ contribute to reduce microbial activity, metabolic rate, chemical and enzymatic changes, as well as avoid mold growth and reduce senescence of fruits, thus extending their shelf life (SONG et al.,2017).

Thus, temperature control, besides the relative humidity, is also important, because changes during storage have a direct effect on quality attributes such as nutritional value, texture, aroma and flavor (CHITARRA, 2005). For this reason, this work aims to analyze different forms of refrigerated storage for strawberries, contributing to the improvement of strawberries shelf life and also to domestic refrigeration processes optimization.

\section{MATERIAL AND METHODS}

\subsection{Material}

Samples were obtained in a commercial establishment in the city of Blumenau in the early morning, taken to the Chemical Tests Laboratory and to the Food Processing Laboratory of the Chemical Engineering Department of the Regional University of Blumenau and also there analyzed. Fresh strawberries were selected for defects absence and packed in polyethylene terephthalate (PET) packaging, covered by polyethylene vinyl film (PVC), without washing. During the analysis period, the samples were stored in a domestic refrigerator (Consul) with an on/off system compressor with 15 thermocouples ( 3 in each shelf). Cooling system was controlled through a program developed using the LabView 15.0 software to guarantee the desired temperature range in this study.

\subsection{Methods}

Mass variation of the strawberry samples was quantified on the $0,2,4$ and 6 day and expressed as a percentage. For this analysis, it was used a semi-analytical balance, with two decimal places, model A1000 (Marte). The methodology of AOAC (2000) was used to determine vitamin C content, 
Recebido em:

$25 / 06 / 2018$

Aceito em:

$03 / 10 / 2018$

which consists on the titration with 2,6-dichloroindophenol solution to determine the ascorbic acid content in the samples. The results were expressed in $\mathrm{mg}$ of ascorbic acid per $100 \mathrm{~g}$ of fruit. Total polyphenol content was determined using the Folin Ciocalteau method (SINGLETON, 1965). The result was expressed in $\mathrm{mg}$ of gallic acid per gram of sample. All analyzes were performed in triplicate, on days 0 (day of receipt of fruits), 2, 4 and 6.

\section{RESULTS AND DISCUSSION}

\subsection{Mass variation}

Mass variation of the strawberry samples shows a reduction during the refrigerated storage period in the two studied temperatures, as shown in Figure 1.

Figure 1 - Strawberry mass variation during refrigerated storage at different temperatures

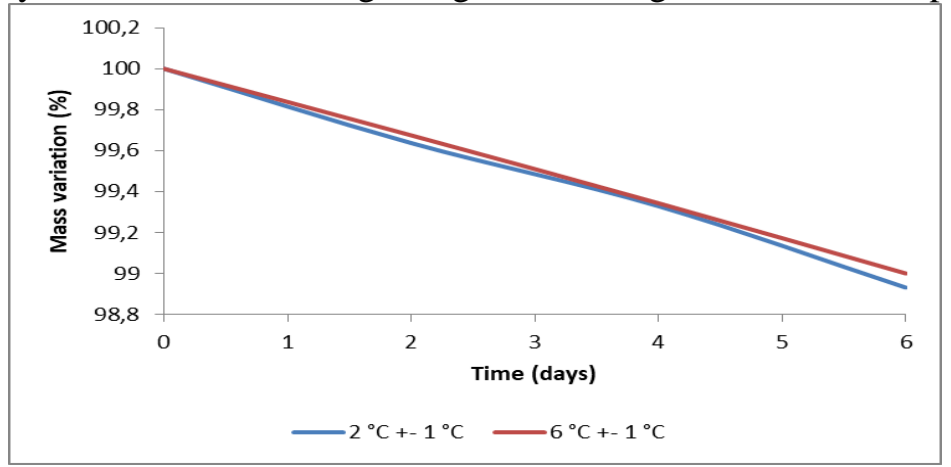

Source: by the author (2018)

Mass loss in fruits is mainly due to perspiration. As the PVC film is a barrier to water vapor, it reduces the loss rate of strawberry mass because an atmosphere with high relative humidity was created inside the package, decreasing the water vapor pressure deficit and consequently the transpiration rate (YAMASHITA et al., 2006). The results obtained in this work are similar to those found by Valenzuela et al. (2015), which obtained $0.50 \%$ strawberry mass variation (Fragaria ananassa), on the fifth day of storage at $5{ }^{\circ} \mathrm{C}$. Ávila et al. (2012) studied strawberry (cv. 'Camino Real') storage at $1{ }^{\circ} \mathrm{C}$ and observed reduction of $8,93 \%$ on the eighth day of storage when compared with the initial mass and Ventura-Aguilar et al. (2018) found approximately $4 \%$ of mass loss at $5{ }^{\circ} \mathrm{C}$ on fifth day storage (cv. 'Camino Real'), this value is well below the results found in this study.

\subsection{Vitamin $\mathrm{C}$ content}

Vitamin C content fluctuated during the storage period, but the final value was lower than values obtained in samples in natura (sample analyzed prior refrigeration) for all treatments (Figure 2). Studies have shown that the increase in the amount of vitamin $\mathrm{C}$ may be related to the stress situation caused by fluctuations in temperature (temperature amplitude of $\pm 1{ }^{\circ} \mathrm{C}$ ) and other environmental factors, which explains the fluctuations in vitamin $\mathrm{C}$ levels observed during refrigerated storage (SANTOS et al., 2012). 
Recebido em:

$25 / 06 / 2018$

Aceito em:

$03 / 10 / 2018$

Figure 2 - Variation of vitamin C content in strawberry during refrigerated storage

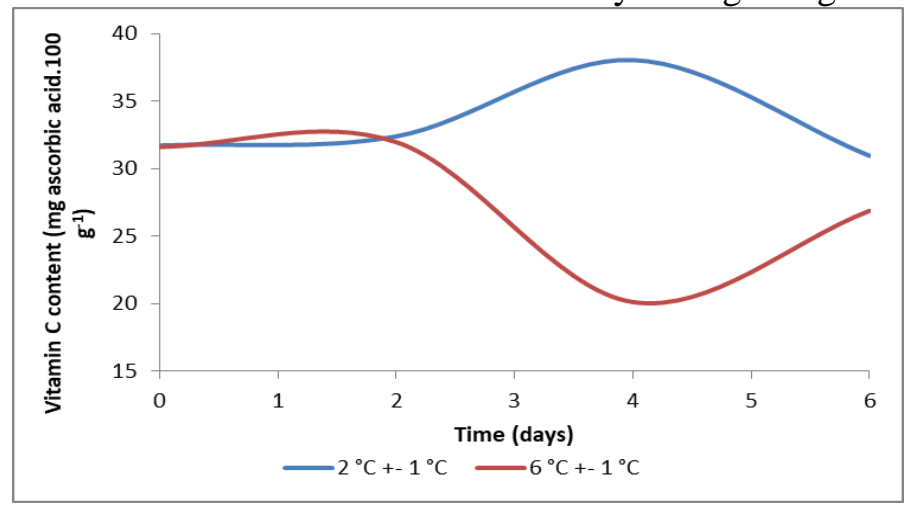

Source: by the author (2018)

According to TACO (2011), the values found for vitamin C in strawberries is $63.6 \mathrm{mg}^{100 \mathrm{~g}^{-1}}$ of the edible part of the fruit. Studies of Samec et al. (2016) also show similar values, being 68.73 mg.100 g ${ }^{-1}$. However, the obtained vitamin $C$ content in this study was somewhat below the values found by the cited authors and these differences may be due to the cultivar studied (FRANÇOSO et al., 2008).

Sogvar et al. (2016) obtained values above that found in this study, with vitamin $\mathrm{C}$ levels of approximately $50 \mathrm{mg} .100 \mathrm{~g}^{-1}$ for Fragaria $x$ anannasa Duch on the sixth day of storage at $1{ }^{\circ} \mathrm{C}$.

\subsection{Total polyphenols}

Figure 3 shows the polyphenols kinetics throughout the storage period. It was observed that the lower temperature $\left(2{ }^{\circ} \mathrm{C}\right)$ maintained higher polyphenols content at the end of the storage. Freire et al. (2013) state that the variation of the polyphenol contents can be affected as a consequence of the variety and crop characteristics, fruit processing and maturity, as well as phenolic compound extraction (solvents, time and temperature), being this the factor that took the oscillations of the results of this study.

Figure 3 - Polyphenols content variation in strawberries throughout the refrigerated storage

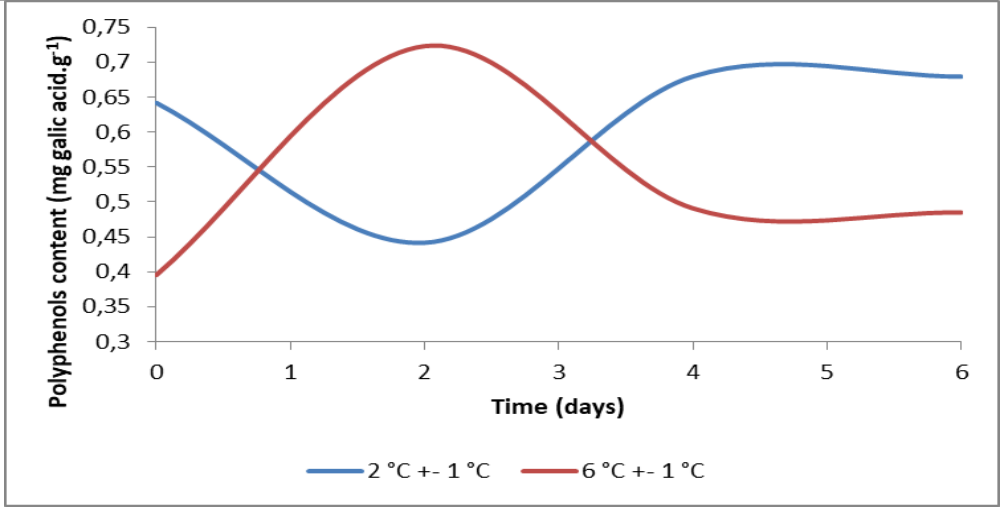

Source: by the author (2018) 
The content of total polyphenols found by Ventura-Aguilar et al. (2018) was $0.55 \mathrm{mg}$ galic acid. $\mathrm{g}^{-1}$ on the fifth day of storage refrigerated at $5{ }^{\circ} \mathrm{C}$, this value is similar to that found in this study for the temperature of $6^{\circ} \mathrm{C} \pm 1{ }^{\circ} \mathrm{C}$ and as in this study. In contrast, Sogvar et al. (2016) obtained a higher value than this study, with approximately $3 \mathrm{mg}$ galic acid.g-1 in strawberries stored at $1^{\circ} \mathrm{C}$ on the sixth day for strawberries Fragaria $x$ anannasa Duch. Authors also verified oscillations during the refrigerated storage period, due to the factors previously mentioned.

\section{CONCLUSION}

Through this study, it was possible to verify that there are differences between the mass variation, Vitamin $\mathrm{C}$ and total polyphenols content during 6 days of refrigerated storage. The temperature of $2{ }^{\circ} \mathrm{C} \pm 1{ }^{\circ} \mathrm{C}$ favored the maintenance of the physicochemical parameters like total polyphenols and Vitamin C. On the other hand, the temperature of $6{ }^{\circ} \mathrm{C} \pm 1{ }^{\circ} \mathrm{C}$ resulted in a lower mass variation when compared with the other temperature studied.

With these results it is possible to optimize domestic refrigeration technology for this food class in order to reduce food and drinking water waste. Moreover, considering the maintenance of the physicochemical parameters, the temperature of $2{ }^{\circ} \mathrm{C} \pm 1{ }^{\circ} \mathrm{C}$ obtained better results for two of the three parameters evaluated.

\section{ACKNOWLEDGEMENTS}

We thank the Regional University of Blumenau and FAPESC for funding.

\section{REFERENCES}

ASSOCIATION OF OFFICIAL ANALYTICAL CHEMISTS, Official Methods of Analysis. 17 ed., Gaithersburg, 2000

AGUAYO, E; JANJASITHORN, R; KADER, A. A. Combined effects of 1-Methylcyclopropene, calcium chloride dip, and/or atmosphere modification on quality changes of fresh-cut strawberries. Postharvest Biology and Technology, v. 40, n. 3, p. 269-278, jun. 2006

ÁVILA, J. M. M.; TORALlES, R. P.; CANTILLANO, R. F. F.; PERALBA, M. C. R.; PIZZOLATO, T. M. Influence of planting system and cold storage on the physical-chemistries characteristicsand volatile compounds development in strawberries. Ciência Rural, v. 42, n. 12, p. 2265-2271, dez. 2012.

CHITARRA, M. I. F.; CHITARRA, A. B. Pós-colheita de frutas e hortaliças: fisiologia e manuseio. 2 ed. Lavras: UFLA, 2005. 
FRANÇOSO, I. L. T.; COUTO, A. L.; CANNIATTI-BRAZACA, S. G.; ARTHUR, V. Alterações físico-químicas em morangos (Fragaria anassa Duch.) irradiados e armazenados. Ciência e Tecnologia de Alimentos, Campinas, v. 28, n. 3, p. 614-619, jul/set. 2008.

FREIRE, J. M.; ABREU, C. M. P.; ROCHA, D. A.; CORRÊA, A. D.; MARQUES, N. R. Quantificação de compostos fenólicos e ácido ascórbico em frutos e polpas congeladas de acerola, caju, goiaba e morango. Ciência Rural, Santa Maria v. 43, n. 12, p. 2291-2296, jun. 2013.

GARCIA, L. C. Aplicação de coberturas comestíveis em morangos minimamente processados. Campinas: Universidade Estadual de Campinas, 2009.

HERNÁNDEZ-MUÑOZ, P.; ALMENAR, E.; VALLE, V. D.; VELEZ, D.; GAVARA, R. Effect of chitosan coating combined with postharvest calcium treatment on strawberry (Fragaria $\times$ ananassa) quality during refrigerated storage. Food Chemistry, Amsterdan, v. 110, n. 2, p 428435, set. 2008.

MORAES, I. V. M.; CENCI, S. A.; BENEDETTI, B. C.; MAMEDE, A. M. G. N.; SOARES, A. G.; BARBOZA, H. T. G. Características físicas e químicas de morango processado minimamente e conservado sob refrigeração e atmosfera controlada. Ciência e Tecnologia de Alimentos, Campinas, v.28, n. 2, p. 274-271, abr/jun. 2008

SAMEC, M.; MARETIC, M.; LUGARIC, I.; MESIC, A.; SALOPEK-SONDI, B.; DURALIJA, B. Assessment of the diferences in the physical, chemical and phytochemical properties of four stawberry cultivars using principal componente analysis. Food Chemistry, Amsterdan, v. 194, p. 828-834, mar. 2016.

SANTOS. H.S; MURATORI, M.C.S.; MARQUES, A.L.A.; ALVES, V.C.; CARDOSO FILHO, F.C.; COSTA, A.P.R. Avaliação da eficácia da água sanitária na sanitização de alfaces (Lactuca sativa). Revista Instituto Adolfo Lutz, São Paulo, v. 71, n. 1, p. 56-60, 2012.

SANTOS J.S. ; OLIVEIRA M.B.P.P. Revisão: alimentos frescos minimamente processados embalados em atmosfera modificada. Brazilian Journal of Food Technoly, v. 15, n. 1, p. 1-14, 2012.

SINGLETON, V. L.; ROSSI JUNIOR, J. A. Colorimetry of total phenolics with phosphomolybdic-phosphotungstic acid reagents. American Journal of Enology and Viticulture, Davis, v. 16, p. 144-158, jan. 1965.

SOGVAR, O. B., SABA, M. K., EMAMIFAR, A., \& HALLAJ, R. Influence of nano-ZnO on microbial growth, bioactive content and postharvest quality of strawberries during storage. Innovative Food Science \& Emerging Technologies, v. 35, 168-176, Mai. 2016. 


\section{Recebido em:}

$25 / 06 / 2018$

Aceito em:

$03 / 10 / 2018$

SONG, H.; WANG, X.; HU, W.; YANG, E. D.; SHEN, T.; QIANG, Q. A cold-induced phytosulfokine peptide is related to the improvement of loquat fruit chilling tolerance. Food Chemistry, Amsterdan, v. 232, p. 434-442, oct. 2017.

TACO: Tabela Brasileira de Composição de Alimentos. 4 ed., Campinas: Universidade Estadual de Campinas, 2011

VALENZUELA, C.; TAPIA, C.; LÓPEZ, L.; BUNGER, A.; ESCALONA, V.; ABURGOCH, L. Effect of edible quinoa protein-chitosan based films on refrigerated strawberry (Fragaria $\times$ ananassa) quality. Electronical Journal of Biotechnology, Valparaíso, v. 18, n. 6, p. 406-411, nov. 2015.

VENTURA-AGUILAR, R. I.; BAUTISTA-BAÑOS, S.; FLORES-GARCÍA, G.; ZAVALETAAVEJAR, L. Impact of chitosan based edible coatings functionalized with natural compounds on Colletotrichum fragariae development ans the quality of strawberries. Food Chemistry, Amsterdan, v. 262, p. 142-149, Abr. 2018

YAMASHITA, F.; VEIGA, G. F.; BENASSI, M. T.; ROBERTO, S. R. Strawberries packaged with polyvinyl chloride (PVC) film. Semina: Ciências Agrárias, Londrina, v. 27, n. 3, p. 429436, jul/set. 2006. 